\title{
When a groin lump is more than a simple groin lump
}

\author{
G Malietzis, ${ }^{1}$ C B Tang, ${ }^{2}$ G Makris, ${ }^{2}$ T Graja ${ }^{1}$ \\ 1Department of General Surgery, Broomfield Hospital, Broomfield, Chelmsford, UK; \\ ${ }^{2}$ Division of Vascular Surgery, Imperial College of London, London, UK
}

Correspondence to Dr G Malietzis, gmalietzis@hotmail.com

\section{Summary}

Groin lump secondary to avulsion fracture of the adductor muscles of the middle thigh in the absence of any hernia is rare. The authors discuss a case of a young footballer who presented with a painful groin swelling. Surgical exploration revealed that the cause of the lump was an avulsion fracture of the adductor muscles.

\section{BACKGROUND}

Avulsion fracture of the adductor muscles of the middle thigh is a rare phenomenon. ${ }^{1}$ We report a case of a footballer with such a fracture presenting as a groin lump as a result of physical exertion.

\section{CASE PRESENTATION}

A 23-year-old male footballer developed a painful swelling in his right groin during sports practice. It occurred while sprinting and appeared in his right, medial groin. On examination, the lump was $2 \mathrm{~cm}$ in diameter, tender to touch and irreducible. There was no cough impulse and the thigh was fixed in external rotation. Adduction of the thigh was especially painful and he found it difficult to weight-bear. Abdominal examination was negative and both abdominal x-ray and blood tests were within normal limits. A diagnosis of an incarcerated groin hernia was made and he was referred to the surgical team on-call.

\section{DIFFERENTIAL DIAGNOSIS}

This includes inguinal and obturator herniae, saphena varix, enlarged lymph gland and psoas abscess.

\section{TREATMENT}

The patient was kept nil by mouth and resuscitated with intravenous fluids. Urgent exploration of the groin was via a high inguinal approach. Haemorrhagic contusions were noted in both the subcutaneous fat layer and inside the inguinal canal but no evidence of either a direct or an indirect inguinal hernia was found. Further exploration revealed a blood clot-filled cavity, below the inguinal canal and extending to the medial superior thigh, within which a $1-\mathrm{cm}$ bone fragment was found attached to the adductor muscles. After taking orthopaedic advice, the fragment was excised and the wound closed.

\section{OUTCOME AND FOLLOW-UP}

The patient recovered well and was discharged home $24 \mathrm{~h}$ later with oral analgesia and instructions to avoid heavy lifting for the next 2 weeks.

\section{DISCUSSION}

Diagnosis of groin lumps can be challenging to physicians of every grade. Detailed attention should be paid to the history and the exact characteristics of the lump during clinical examination. The physical appearance of the lump, its reducibility, presence of cough impulse and neurological examination will all aid in differentiating a hernia. A vascular examination is mandatory if saphena varix, femoral aneurysm or pseudo-aneurysm is suspected. Fever, night sweats and weight loss suggest lymphoma whereas the presence of infection alone would be more suggestive of a pelvic collection.

Adductor avulsion fractures presenting as groin lumps are rare. The adductors consist of the medial thigh muscles and are attached proximally to the anteroinferior exterior of the bony pelvis and distally to the linea aspera of the femur. ${ }^{2}$ As yet, we can find no reference to this in the literature. Adductor strain and resultant groin pain is one of the commonest conditions in athletes. ${ }^{3}$ In football players, groin injuries occur in 11-17 per 100 athletes, of which $61 \%$ are due to adductor muscle strain. ${ }^{4}$ Painful adduction of the thigh against resistance and tenderness on palpating the muscle are pathognomonic of this condition. ${ }^{56}$

\section{Learning points}

- Diagnosis of groin lumps in athletes can be complicated by the complex musculoskeletal anatomy.

- Adductor strain is very common in athletes with various presentations.

- When forming a differential, one must think beyond the surgical sieve and not forget that a groin consists of muscle and bone as well.

Competing interests None.

Patient consent Obtained.

\section{REFERENCES}

1. Renström P, Peterson L. Groin injuries in athletes. Br J Sports Med 1980;14:30-6. 


\section{BMJ Case Reports}

2. Morelli V, Smith V. Groin injuries in athletes. Am Fam Physician 2001;64:1405-14.

3. Hoelmich P. Adductor-related groin pain in athletes. Sports Med Arthroscopy Rev 1997;5:285-91

4. Ekberg 0, Persson NH, Abrahamsson PA, et al. Longstanding groin pain in athletes. A multidisciplinary approach. Sports Med 1988;6:56-61.
5. Boyd KT, Peirce NS, Batt ME. Common hip injuries in sport. Sports Med 1997;24:273-88.

6. Anderson MW, Kaplan PA, Dussault RG. Adductor insertion avulsion syndrome (thigh splints): spectrum of MR imaging features. AJR Am J Roentgenol 2001;177:673-5.

This pdf has been created automatically from the final edited text and images.

Copyright 2011 BMJ Publishing Group. All rights reserved. For permission to reuse any of this content visit http://group.bmj.com/group/rights-licensing/permissions.

BMJ Case Report Fellows may re-use this article for personal use and teaching without any further permission.

Please cite this article as follows (you will need to access the article online to obtain the date of publication).

Malietzis G, Tang CB, Makris G, Graja T. When a groin lump is more than a simple groin lump. BMJ Case Reports 2011;10.1136/bcr.12.2010.3607, date of publication

Become a Fellow of BMJ Case Reports today and you can:

- Submit as many cases as you like

- Enjoy fast sympathetic peer review and rapid publication of accepted articles

- Access all the published articles

- Re-use any of the published material for personal use and teaching without further permission

For information on Institutional Fellowships contact consortiasales@bmjgroup.com

Visit casereports.bmj.com for more articles like this and to become a Fellow 